\title{
Adsorption of Cu (II) and Ni (II) Ions from Solution onto Calcium Alginate Beads
}

\author{
1*JALIJA, DO; ${ }^{*}$ UZAIRU, A \\ ${ }^{*}$ Ahmadu Bello University, School of Basic and Remedial Studies, P.M.B. 6007, Funtua, Katsina State, Nigeria. \\ ${ }^{2}$ Department of Chemistry, Ahmadu Bello University, Zaria, Kaduna State, Nigeria. \\ *Corresponding Author Email: danieljalija@yahoo.com
}

\begin{abstract}
The objective of this study was to investigate the biosorption of $\mathrm{Cu}$ (II) and $\mathrm{Ni}$ (II) ions from aqueous solution by calcium alginate beads. The effects of solution $\mathrm{pH}$, contact time and initial metal ion concentration were evaluated. The results showed that maximum $\mathrm{Cu}$ (II) removal $(93.10 \%)$ occurred at $\mathrm{pH}$ of 9.0 , contact time of 120 minutes and initial ion concentration of $10 \mathrm{mg} / \mathrm{L}$ while that of $\mathrm{Ni}$ (II) was $94.6 \%$, which was achieved at $\mathrm{pH}$ of 8.0, contact time of 120 minutes and initial ion concentration of $10 \mathrm{mg} / \mathrm{L}$. The equilibrium data fitted well to the Langmuir Isotherm indicating that the process is a monolayer adsorption. The coefficients of determination, $\mathrm{R}^{2}$, values for the Langmuir Isotherm were 0.9799 and 0.9822 respectively for $\mathrm{Cu}$ (II) and $\mathrm{Ni}$ (II) ions. The values of the maximum biosorption capacity, $\mathrm{Q}^{\circ}$, were 10.79 and $6.25 \mathrm{mgg}^{-1}$ respectively. The kinetic data also revealed that the sorption process could best be described by the pseudo - second order kinetic model. The $\mathrm{R}^{2}$ values for the pseudo - second order kinetic plots for $\mathrm{Cu}$ (II) and $\mathrm{Ni}$ (II) were 0.9988 and 0.9969 respectively. These values were higher than those for the pseudo - first order plots. The values of the biosorption capacity qe obtained from the pseudo - second order plots were very close to the experimental values of $q e$ indicating that the biosorption process follows the second order kinetics. This study has therefore shown that calcium alginate beads can be used for the removal of $\mathrm{Cu}$ (II) and $\mathrm{Ni}$ (II) ions from wastewaters.
\end{abstract}

\section{DOI: https://dx.doi.org/10.4314/jasem.v24i2.20}

Copyright: Copyright (C) 2020 Jalija and Uzaru. This is an open access article distributed under the Creative Commons Attribution License (CCL), which permits unrestricted use, distribution, and reproduction in any medium, provided the original work is properly cited.

Dates: Received: 16 November 2019; Revised: 11 January 2020; Accepted: 22 February 2020

Keywords: Adsorption, Calcium alginate, Isotherm, Langmuir, Pseudo- first order, Pseudo-second order

Environmental pollution by toxic metals is a worldwide problem due to increased industrialisation. The metal ions are particularly problematic due to their accumulation in the food chain and their persistence (Bueno et al., 2008). $\mathrm{Cu}$ (II) and $\mathrm{Ni}$ (II) are among the metals of concern. Nickel is regarded as one of the essential trace elements for humans, plants and animals but it causes toxicity to aquatic life at higher concentrations. Copper is also an essential element for plants, animals and humans but it is also toxic at higher concentrations (Franke et al., 2003).

There are several methods for removing heavy metals from wastewater. Some of these methods include chemical precipitation, ion exchange, electrochemical treatment, membrane technologies, adsorption on activated carbon etc. (Mathieckal and Yu, 1999). However these methods are expensive and may produce harmful by-products (Zvinowanda et al., 2010). Numerous studies have demonstrated that microorganisms have the ability to remove heavy metals from wastewater with better performance and lower cost compared with conventional technologies (Kapoor et al., 1999; Liu et al., 2004; Moon et al., 2006)
Biopolymers such as alginates can uptake metal ions from aqueous solutions. They possess all of the biosorbent advantages and compete with other traditional methods such as ion exchange and activated carbon. Alginates are linear polysaccharides found in many algal species especially in brown algae and are also produced by certain bacteria (Arica et al., 2001). The objective of this study was therefore to determine the adsorption capacity of calcium alginate beads for $\mathrm{Cu}$ (II) and $\mathrm{Ni}$ (II) ions in solution.

\section{MATERIALS AND METHODS}

$100 \mathrm{ml}$ of $4 \%(\mathrm{w} / \mathrm{v})$ sodium alginate was prepared in a volumetric flask and was shaken until it became properly dissolved. The sodium alginate slurry was dropped through a $10 \mathrm{ml}$ syringe into $2 \%(\mathrm{w} / \mathrm{v}) \mathrm{CaCl}_{2}$ solution. Durable spherical beads of the alginates were formed immediately. The beads were washed with distilled water and stored at $4{ }^{\circ} \mathrm{C}$ in distilled water until further use. The studies were carried out using a batch technique. The contact experiments were done in replicates in $100 \mathrm{ml}$ conical flasks containing $50 \mathrm{ml}$ of solution. The flask contents were mechanically agitated on a conical flask shaker at $150 \mathrm{rpm}$ and a temperature of $29^{\circ} \mathrm{C}$. To determine the optimum 
conditions for biosorption, the $\mathrm{pH}$ of the solutions were varied from $3.0-9.0$, contact time from $10-150$ minutes and initial metal ion concentrations were varied from $10-100 \mathrm{mg} / \mathrm{L}$. At the end of the reaction, the contents of the flask were separately filtered into polypropylene bottles using Whatman No 1 filter paper. Atomic Absorption Spectrometer (AAS) was used to determine $\mathrm{Cu}$ (II) and $\mathrm{Ni}$ (II) ion concentrations in the solution before and after contact with the adsorbent. The percentage metal removal (\%) was calculated using the following equation:

Removal \% $=\frac{\left(C_{o}-C_{e}\right)}{C_{o}} \times 100$

The amount of each ion adsorbed was calculated from the difference between the added and equilibrium concentration by using the equation 2 :

$$
q_{e}=\frac{V\left(C_{o}-C_{e}\right)}{M}
$$

Where $q_{e}$ is the amount adsorbed in $\mathrm{mg} / \mathrm{g}$ of the absorbent at equilibrium, $C_{o}$ and $C_{e}$ are the initial and the equilibrium concentrations in $\mathrm{mg} / \mathrm{L}$, respectively, $V$ is the volume in litres of the solution used during the experiment and $M$ is the mass of the adsorbent in grams.

The experimental results were fitted to the Langmuir isotherm model as given by the equation

$\frac{C_{e}}{q_{e}}=\frac{1}{K_{L} Q^{o}}+\frac{C_{e}}{Q^{o}}$

Where $K_{\mathrm{L}}(\mathrm{L} / \mathrm{g})$ is a constant related to the adsorption / desorption energy and $\mathrm{Q}^{\circ}(\mathrm{mg} / \mathrm{g})$ is the maximum sorption upon complete saturation of the adsorption of the adsorbent (biosorbent) surface (Akgerman and Zardkoohi, 1996). A graph of $\mathrm{C}_{\mathrm{e}} / \mathrm{q}_{\mathrm{e}}$ against $\mathrm{C}_{\mathrm{e}}$ will have $\mathrm{K}_{\mathrm{L}}(\mathrm{L} / \mathrm{g})$ as the slope and $\mathrm{Q}^{\circ}(\mathrm{mg} / \mathrm{g})$ as the intercept.

The experimental data for the adsorption process were fitted to the Pseudo - first order (Equation 4) and Pseudo - second order (Equation 5) kinetic models.

$\log \left(q_{e}-q_{t}\right)=\log q_{e}-\frac{k_{1}}{2.303} t$

Where $\mathrm{q}_{\mathrm{e}}(\mathrm{mg} / \mathrm{L})$ and $\mathrm{q}_{\mathrm{t}}(\mathrm{mg} / \mathrm{L})$ are the adsorption capacities at equilibrium and at time $\mathrm{t}$ respectively. $k_{l}$ ( $\mathrm{L} / \mathrm{min})$ is the rate constant for a pseudo -first order adsorption. A plot of $\log \left(\mathrm{q}_{\mathrm{e}}-\mathrm{q}_{\mathrm{t}}\right)$ against $\mathrm{t}$ gave a straight line from which $\mathrm{k}_{1}(\mathrm{~L} / \mathrm{min})$ and $\mathrm{q}_{\mathrm{e}}(\mathrm{mg} / \mathrm{L})$ were determined from the slope and intercept of the plot respectively.

$$
\frac{1}{q_{t}}=\frac{1}{k_{2} q_{e}^{2}}+\frac{t}{q_{e}}
$$

Where $\mathrm{q}_{\mathrm{e}}(\mathrm{mg} / \mathrm{L})$ and $\mathrm{q}_{\mathrm{t}}(\mathrm{mg} / \mathrm{L})$ are the adsorption capacities at equilibrium and at time $t$ respectively and $\mathrm{k}_{2}$ (g/mgmin) is the rate constant for a pseudo - second order adsorption. A plot of $\mathrm{t} / \mathrm{q}_{\mathrm{t}}$ against $\mathrm{t}$ gave a linear plot from which $\mathrm{q}_{\mathrm{e}}$ and $k_{2}$ were determined from the slope and intercept respectively.

\section{RESULTS AND DISCUSSION}

Effect of Solution $\mathrm{pH}$ : The effect of the solution $\mathrm{pH}$ on the removal of $\mathrm{Cu}$ (II) and $\mathrm{Ni}$ (II) ions from solution is presented in Fig 1. The removal percentage of both ions increased with an increase in solution $\mathrm{pH}$. The removal percentage for $\mathrm{Cu}$ (II) increased from $7.5 \%$ at $\mathrm{pH} 3.0$ to $93.10 \%$ at $\mathrm{pH} 9.0$. The maximum adsorption of $\mathrm{Ni}$ (II) was $94.86 \%$ at $\mathrm{pH} 8.0$ while the lowest was $1.42 \%$ at $\mathrm{pH} 3.0$. The increase in metal ion removal with increase in $\mathrm{pH}$ is due to a decrease in competition between protons and the metal cations for the surface sites and by the decrease in positive surface charge which results in a lower coulombic repulsion of the sorbing metal cation (Ghorbani et al., 2008). Ozer and Ozer, (2003) and Ghorbani et al. (2008) have reported similar results.

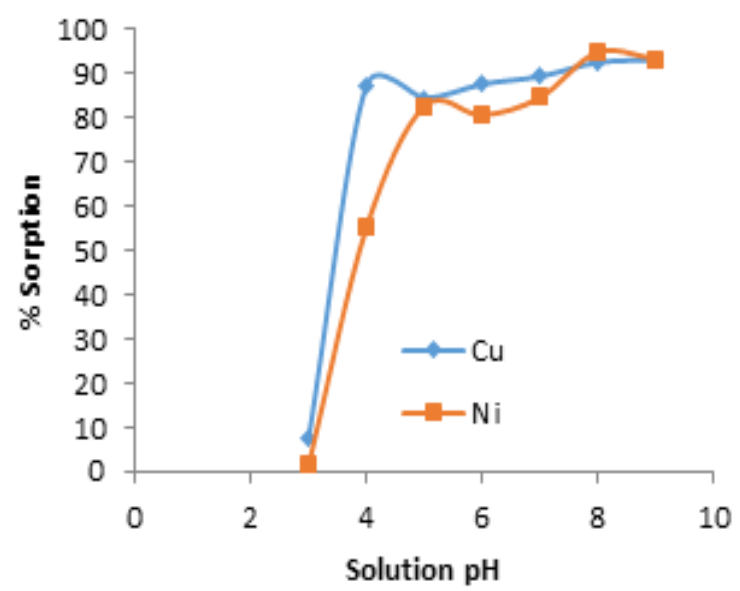

Fig 1. Effect of solution $\mathrm{PH}$ on adsorption of $\mathrm{Cu}$ (II) and $\mathrm{Ni}$ (II) onto calcium alginate beads

Effect of contact time on adsorption of $\mathrm{Cu}$ (II) and $\mathrm{Ni}$ (II) ions: The effect of the contact time on the removal of $\mathrm{Cu}$ (II) and $\mathrm{Ni}$ (II) ions from solution is presented in Fig 2. The removal percentage of the $\mathrm{Cu}$ (II) ions increased from $77.57 \%$ at 10 minutes to the maximum of $91.04 \%$ at 120 minutes. The removal percentage of $\mathrm{Ni}$ (II) ions by the biosorbent increased from $61.18 \%$ at 10 minutes contact time to $81.21 \%$ at 120 minutes. There was a general increase in removal percentage from the beginning which later became stable with 
time. As the adsorption process proceeded, the adsorbate reached the saturation state and then the adsorbate tended to desorb back into the solution. Eventually the rates of adsorption and desorption became equal at equilibrium (Sari and Tuzen, 2008).

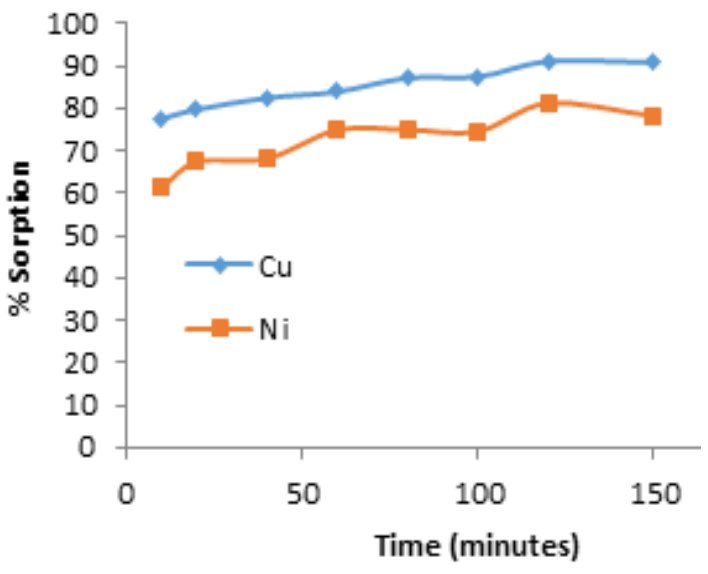

Fig 2 Effect of contact time on adsorption of $\mathrm{Cu}$ (II) and $\mathrm{Ni}$ (II) onto calcium alginate beads

Effect of initial metal ion concentration: The effect of initial metal ion concentration on the removal of $\mathrm{Cu}$ (II) and Ni (II) ions from solution is shown in the Fig 3. The removal percentage of $\mathrm{Cu}$ (II) ions decreased from $87.50 \%$ at $10 \mathrm{mg} / \mathrm{L}$ to $29.66 \%$ at $100 \mathrm{mg} / \mathrm{L}$. For $\mathrm{Ni}$ (II) the removal percentage decreased from $79.49 \%$ at $10 \mathrm{mg} / \mathrm{L}$ to $17.89 \%$ at $100 \mathrm{mg} / \mathrm{L}$ metal ion concentration. Occurrence of more unoccupied surface binding sites on the adsorbent at low concentration of metal ions could possibly be responsible for higher removal efficiency at low concentration. But as the concentration increased, the number of ions competing for available binding sites on the adsorbent increased and hence the adsorption of metal ions decreased (Shoaib et al., 2013).

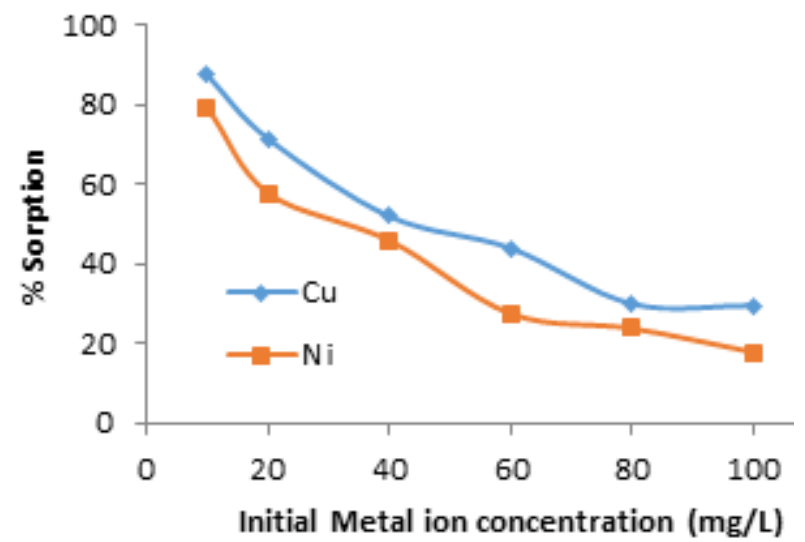

Fig 3 Effect of initial ion concentrations on adsorption of $\mathrm{Cu}$ (II) and $\mathrm{Ni}$ (II) onto calcium alginate beads

Langmuir Isotherm: The Langmuir isotherm for the biosorption of $\mathrm{Cu}$ (II) and $\mathrm{Ni}$ (II) by calcium alginate beads is presented in Fig 4. The values of the coefficient of determination, $\mathrm{R}^{2}$, for Langmuir equations for $\mathrm{Cu}$ (II) and $\mathrm{Ni}$ (II) were 0.9799 and 0.9822 respectively. Both exhibited high $\mathrm{R}^{2}$ values. Both ions therefore, exhibited a good fit of their equilibrium data for the Langmuir model which indicates a monolayer adsorption. Maximum biosorption capacity $\mathrm{Q}^{\circ}\left(\mathrm{mg} \mathrm{g}^{-1}\right)$ for $\mathrm{Cu}$ (II) and $\mathrm{Ni}$ (II) were calculated to be 10.79 and $6.25 \mathrm{mg} \mathrm{g}^{-1}$ respectively.

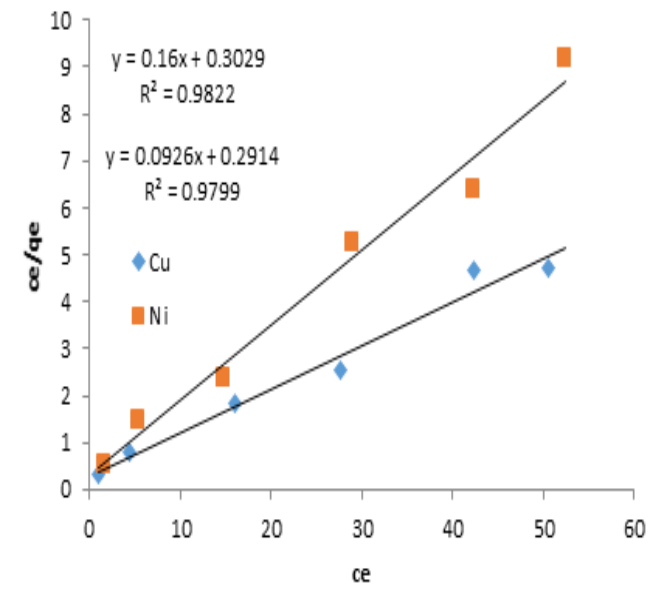

Fig 4 Langmuir Isotherm for the adsorption of $\mathrm{Cu}$ (II) and $\mathrm{Ni}$ (II) ions onto calcium alginate beads

\section{Adsorption Kinetics}

Pseudo - first order kinetics: The pseudo - first order kinetic plots for the adsorption of $\mathrm{Cu}$ (II) and $\mathrm{Ni}$ (II) onto calcium alginate beads is shown in Fig 5. The correlation coefficient, $\mathrm{R}^{2}$, for the pseudo - first order kinetic plot for the ions were 0.9468 and 0.9146 respectively. The values of $q e$ and $k_{l}$ obtained from the plots are shown in Table 1 . From the table it cab be seen that the calculated values of $q e$ were not in agreement with the experimental values. These results suggest that the biosorption of $\mathrm{Cu}$ (II) and $\mathrm{Ni}$ (II) onto the biosorbent can not be described by the pseudo first order kinetic model.

Pseudo-second order kinetics: The pseudo - second order kinetic plots for the adsorption process is presented Figure 6 . The pseudo - second order kinetic plot shows the $\mathrm{R}^{2}$ values for the $\mathrm{Cu}$ (II) and $\mathrm{Ni}$ (II) ions to be 0.9988 and 0.9969 respectively. The values of $q e$ and $k_{2}$ obtained from the plots are shown in Table 1. The $\mathrm{R}^{2}$ values were high and very close to unity. Also the value of the theoretical and experimental qe were the same for $\mathrm{Ni}$ (II) but the values for $\mathrm{Cu}$ (II) were slightly different as shown in the table. These results indicate that the biosorption reaction follows the pseudo - second order kinetic model and that chemisorption is the rate controlling mechanism (Mata et al., 2008). 


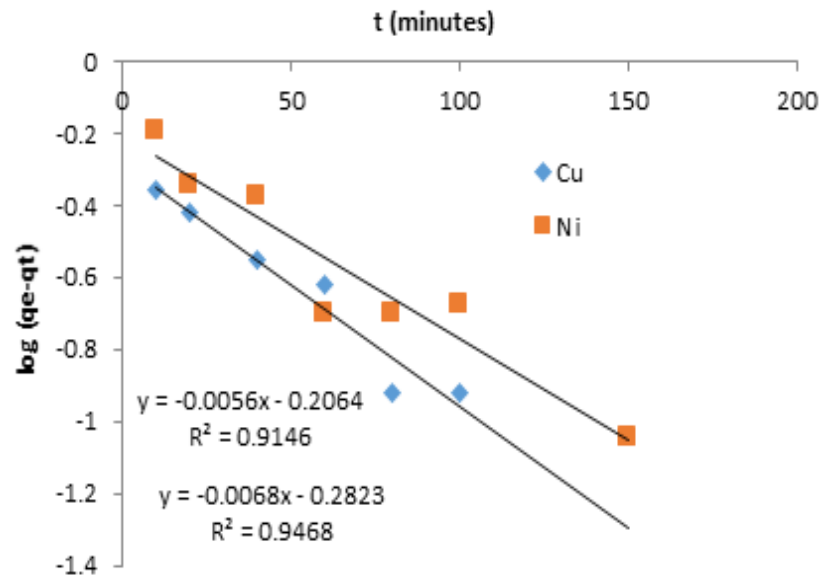

Fig 5 Pseudo - first order kinetic plot for the adsorption of $\mathrm{Cu}$ (II) and $\mathrm{Ni}$ (II) ions onto calcium alginate beads

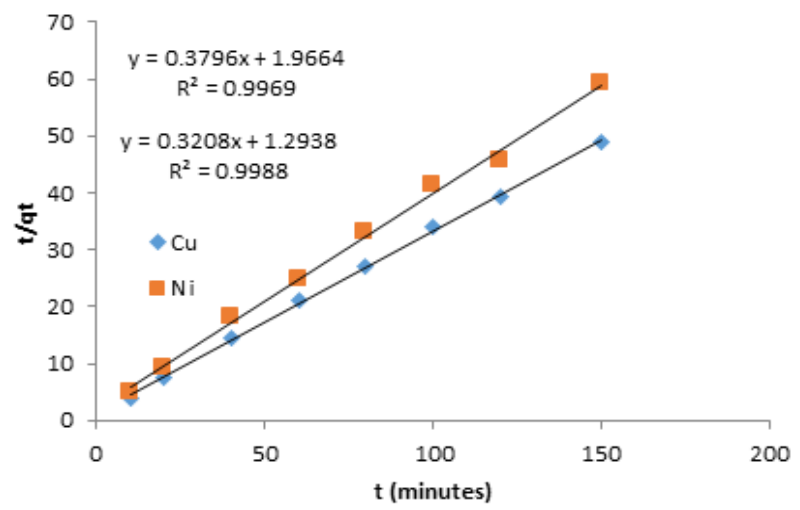

Fig 6 Pseudo - second order kinetic plot for the adsorption of $\mathrm{Cu}$ (II) and $\mathrm{Ni}$ (II) ions onto calcium alginate beads

Table 2 Pseudo - first and second order constants for the adsorption of $\mathrm{Cu}$ (II) and $\mathrm{Ni}$ (II) ions onto calcium alginate beads

\begin{tabular}{llllllll}
\hline & & \multicolumn{2}{l}{ Pseudo - first order constants } & \multicolumn{3}{l}{ Pseudo - second order constants } \\
\hline & $q e$ (experimental) & $\mathrm{R}^{2}$ & $\mathrm{k}_{1}$ & $q e$ (calculated) & $\mathrm{R}^{2}$ & $\mathrm{k}_{2}$ & qe(calculated) \\
\hline $\mathrm{Cu}(\mathrm{II})$ & 1.53 & 0.9464 & 0.016 & 0.52 & 0.9988 & 0.079 & 3.12 \\
$\mathrm{Ni}(\mathrm{II})$ & 2.63 & 0.9146 & 0.013 & 0.62 & 0.9969 & 0.074 & 2.63 \\
\hline
\end{tabular}

Conclusion: The results of this study have shown that calcium alginate beads can be utilized for the removal of $\mathrm{Cu}$ (II) and $\mathrm{Ni}$ (II) ions from solution. The removal efficiency of both ions by the adsorbent increased with increase in $\mathrm{pH}$. The experimental data fitted the Langmuir Isotherm well for both ions indicating a monolayer adsorption. The kinetic modeling shows that the pseudo - second order model had a better fit than the pseudo - first order model.

\section{REFERENCES}

Akgerman, A; Zardkoohi, M (1996). Adsorption of phenolic compounds on fly ash. J. Chem. Eng. Data. 41: 185 - 191

Arica, MY; Kacar, Y; Genc, O (2001). Entrapment of white-rot fungus Trametes vesicolor in ca alginate beads: Preparation and biosorption kinetic analysis for cadmium removal from an aqueous solution. J. Biosor. Technol. 80(2): 121 129.

Bueno, BYM; Torem, ML; Molina, F; de Mesquita, LMS (2008). Biosorption of lead (II), chromium (II) and copper (II) by R.opacus: equilibrium and kinetic studies. Minerals Eng. 21(1): 65 -75

Franke, S; Grass, G; Rensing, C; Nies, DH (2003). Molecular analysis of the copper - transporting efflux System CusCFBA of Escherichia coli. $J$. Bacteriol. 185: 3804 - 3812

Ghorbani, N; Younesi, H; Ghasempouri, SM; Zinatizadeh, AA; Amini, M.; Daneshi, A (2008). Application of response surface methodology for optimization of cadmium biosorption in an aqueous solution by Saccharomyces cerevisiae. Chem. Eng. J. 145: 267 - 275 
Kapoor, A; Viraraghavan, T; Cullimore, DR (1999). Removal of heavy metals using the fungus Aspergillus niger. Bioresour. Technol. 70: $95-$ 104

Liu, HL; Chen, BY; Lan, YW; Cheng, WC (2004). Biosorption of $\mathrm{Zn}$ (II) and $\mathrm{Cu}$ (II) by the indigenous Thiobacillus thiooxidans. Chem. Eng. J. 97: $195-201$

Matheickal, JT; Yu, Q (1999). Biosorption of cadmium (II) from aqueous solution by pretreated biomass of marine algae Durvillaea potatorium. Water Res. 33: $335-343$

Mata, YN; Blazquez, ML; Ballester, A; Gonzalez, F; Munoz, JA (2008). Characterization of the biosorption of cadmium, lead and copper with brown algae Fucus vesiculosus. J. Hazard. Mater. 158: $316-323$

Moon, SH; Park, CS; Kim, YJ; Park,YI (2006). Biosorption isotherms of $\mathrm{Pb}$ (II) and $\mathrm{Zn}$ (II) on Pestan, an extracellular polysaccharide of Pestalotiopsis sp. KCTC8637P. Process Biochemistry, 41: 312 - 316
Ozer, A; Ozer, D (2003). Comparative study of the biosorption of $\mathrm{Pb}$ (II), $\mathrm{Ni}$ (II), $\mathrm{Cr}$ (VI) ions onto Saccharomyces cerevisiae: Determination of biosorption heats. J. Hazard. Mater. 100: 219 229

Sari, A; Tuzen, M (2008). Biosorption of cadmium (II) from aqueous solution by red algae (Ceramium virgatum): equilibrium, kinetic and thermodynamic studies. J. Hazard.Mater. 157(23): $448-454$

Shoaib, A; Aslam, N; Aslam, N (2013). Trichoderma harzianum: desorption, isotherm and FTIR studies. The J. Animal and Plant Sciences. 23(5): $1460-1465$

Zvinowanda, CM; Okonkwo, JO; Agyei, NM; Staden, MV; Jordan, W (2010). Recovery of lead (II) from aqueous solution by Zea mays tassel biosorption. Amer. J. Biochem. Biotechnol. 6: 1-10 